\title{
In Defence of Monarchy
}

\author{
Bryan S. Turner
}

Published online: 2 December 2011

(C) Springer Science+Business Media, LLC 2011

\section{Aristocracy in the Colonial American Imagination}

Historically American opposition to monarchy has been connected to a wider opposition to aristocracy. What has come to characterise American attitudes to individual liberties is a long lasting hostility to the 'idle rich'. In this respect, the Thorstein Veblen's notion of the 'leisure class' was an ironic reflection on American social structure; leisure was not officially an important aspect of core American values. The definition of citizenship in this context came to be associated not so much with the need for 'honest toil', but with the autonomy and self-respect that attended employment as a worker. Judith N. Shklar (1991:67), arguably the leading political writer on American citizenship, claimed that "We are citizens only if we "earn". From a jurisprudential perspective, there is a necessary connection between right and duty, and therefore earning an income is crucial if citizens are to fulfill their obligations to the community in paying their taxes, and maintaining a household.

However, for writers like Shklar there is deeper moral meaning to working for a living. In colonial America, the two social groups in society not involved in working for an income were slaves and aristocrats-the former were involuntarily excluded from the dignity of waged work, while the latter were privileged by the inheritance of wealth and could voluntarily avoid the necessity of work. The accident of birth either as a slave or as an aristocrat was to be expunged from the social landscape of a revolutionary democracy. The problem of aristocratic privilege is not

B. S. Turner $(\bowtie)$

Graduate Center, City University of New York,

365 Fifth Avenue,

New York, NY 10016-4309, USA

e-mail: bturner@gc.cuny.edu easily resolved and for Shklar (1991:85) these attitudes persist in contemporary America: "Resentment of the idle monopolist and aristocract, and fear of being reduced to the condition of a black slave, or of a black second-class citizen, have not disappeared, because they are grounded in lasting political experiences."

The founders of Jacksonian democracy feared that aristocracy could be easily re-established in America and that constant vigilance was required to prevent such a regressive development. In the European context, aristocracy referred to the privileges associated with the hereditary ownership of land and the privileges, titles and status that came with it. In the American colonies, it came to mean elitism of any sort, but more specifically it referred to the few who would scheme and plot to use the powers of political office against the many. In the 1780 s there was widespread anxiety among country democrats that the wealthy men who sought to run the state would reduce them to a new form of vassalage. These democratic impulses for social equality were further enhanced by the spread of evangelical influence with the New England Great Awakening which pitched evangelicals from the rural hinterland against the Anglican gentry of the seaboard states. These country democrats joined hands with the 'urban yeomanry' of New York to oppose any legacy of aristocratic privilege, including clerical privilege. For example, they opposed the draft provisions of the 1780 Constitution that required public financial support for Congregational churches (Wilentz 2005: 19). These democrats feared a 'new aristocracy of monopolists and especially the men who ran the Bank of the United States'(1991:66) and therefore they assumed there was a danger that the rights of the industrious working class would be 'sapped by crafty and indolent bankers' (1991:74). Attempts to introduce property qualifications 
for the election of senators were opposed and it was Benjamin Franklin pointed out that it was important not to suppress the virtue and public spirit of the ordinary people. The real difference he argued between Britain and America was the way in which the common people were treated and respected in a democracy. Therefore, the role of the Constitution of the United States was to protect honest working men from such parasitic elites.

The problem for democracies comes to depend, not on property as a qualification necessary for the franchise, but on the quality of the electorate itself. In the context of a mass democracy, education was crucial to ensure the survival of virtue, especially among young men, to protect them from any regression towards aristocratic vices. As we know, the exchange of letters between John Adams and Thomas Jefferson regarding the character of aristocracy constitutes an important contribution to political theory (Ellis 1993). For Adams, aristocracy meant any individual or group who sought undue influence through controlling or manipulating the vote of others While Jefferson feared 'the one' (the king) Adams feared 'the few' or the potential for a different type of political aristocracy of privilege. But the difference was in fact more profound since Jefferson sought, especially in his educational plans for Virginia, to create a 'natural aristocracy' based on virtue and talent. Adams feared that over time an aristocracy of talent would lead to repressive regimes. Adams's ideas continued to influence political opinions through the nineteenth century, although they were often no longer openly acknowledged (Shklar, 1999b:152). An educated citizenry was assumed to be necessary if the common people were to defend their rights, participate in politics, and enjoy the self-respect that education offers. They would become a balwark against any back-sliding into aristocratic vice.

Adams and Jefferson fundamentally parted company over the issue of the causes of social inequality. Adams thought inequalities were natural and inevitable, and hence part of the 'constitution of Human Nature' and that no policy, however enlightened, could reduce the differences of condition between individuals. Jefferson responded in October 1813 to say that while aristocratic families had dominated European history, in America aristocratic privilege such as primogeniture and entail had long been banished and that everyone in America had sufficient land to labour for himself if he so chose. The law had removed 'rank and birth, and tinsel-aristocracy'. For Adams a classless Jeffersonian democracy would only deepen the struggle for wealth and prestige; for Jefferson, the prospect of a society based on effort and merit was the very cornerstone of the American revolution. The founding fathers would have been shocked if not dismayed by the enthusiasm for the Royal Wedding among the American public in the early months of 2011.

\section{Constitutional Monarchy}

The conflict with the British monarchy can therefore be seen as simply one component of a more general hostility to elitism, privilege and office that was expressed in different ways by Jefferson, Adams and Madison. These republican ideals came together in opposition to George111 (17381820) whose rule was regarded as arbitrary and tyrannical. He was the third Hanovarian, but he was born in Britain and spoke English as his first language. He was famously insane, suffering from what was subsequently diagnosed as porphyria. Twentieth-century historians have been revisionist in exonerating George111 from any significant responsibility for the causes that produced the American Revolution. Indeed he is not seen as a tyrant but rather as a king who acted as a constitutional monarch, at least in the final years of his reign, in supporting the policies of his ministers and attending to the mood of parliament (Black 2006; Butterfield 1957; Pares 1953). Furthermore, 'Farmer George' who was pious and thrifty contributed to the agricultural improvement of Britain, was warmly regarded by the public as a loyal husband and only Queen Victoria reigned for a longer period of time. After the Act of Union in 1801 that created the United Kingdom of Great Britain and Ireland, George rejected the proposal that he adopt the title of 'The Emperor of the British Isles'. As the monarchy lost its political power in key institutions such as parliament, it evolved as a symbol of national coherence, especially in the context of the prospect of a French invasion in 1803 .

The basis of constitutional monarchy in Great Britain can be traced back to the Glorious Revolution of 1688 , to the Bill of Rights in 1689 and to the Act of Settlement in 1701, but the theory of constitutional monarchy was not fully articulated until Walter Bagehot (1826-1877) published his famous treatise on constitutionalism in 1867. A businessman, journalist and lawyer, Bagehot founded the National Review and became the chief editor of The Economist. He is however remembered primarily as the author of The English Constitution which examined the functions of parliament and monarchy through a comparison of Britain and America. It was published in the same year as the Reform Act of 1867, which required Bagehot to produce a new introduction to the second edition. This work appeared in the reign of Queen Victoria (1819-1901), who came to the throne in 1837 and in some respects we can regard The English Constitution as both a tribute to her reign and a description of the constitutional monarchy that was emerging out of it.

Bagehot divided the functions of the constitution into two separate components. The Dignified aspect referred to various symbolic functions whereas the Efficient element was concerned with how things get done. We might argue 
that in the century following Bagehot the symbolic functions of monarchy have increased, while the symbolic significance of parliament has declined as parliamentary affairs have been subject to what Max Weber regarded as legal-rationality.

Bagehot argued that the Reform Act had deepened and extended the consequences of the Reform Act of 1832 by giving greater voice to the middle class, The social changes occurring in Britain were reflected in the composition of parliament where the aristocracy was in decline, he proposed that 'our present House of Commons is plutocratic, not aristocratic' and that the parliamentarians were now closely connected with 'the new trading wealth' (Bagehot 2009:8). The House of Lords could exert 'aristocratic guidance' but they no longer had significant control. Although Bagehot was only too aware of the social changes taking place that were also bringing about constitutional changes, his arguments in favour of monarchy have retained a certain contemporary relevance.

Firstly he argued that, while the great majority of the people could not understand in abstract terms the meaning and importance of the constitution as a set of procedures, they could readily grasp the symbolic significance of the monarch. The people were connected to the monarchy by emotion rather than by reason. He also believed that the function of the royal family was extremely important. While on the surface the emotional appeal of the marriage of the Prince of Wales might appear 'childish', women 'care 50 times more for a marriage than a ministry' (Bagehot 2009:37). Furthermore, 'the Americans were more pleased at the Queen's letter to Mrs. Lincoln than at any act of the English Government' (Bagehot 2009:37). Secondly, monarchy contributes religion to the strengthening of government. Although Bagehot was critical of the person of George111, he believed that in Victorian England the oath of allegiance was enormously significant in securing the loyalty of the people to the underlying principles of the constitution. While the country was divided into parties, 'the crown is of no party' (Bagehot 2009:40) and hence it can function to stabilise the society as a whole. Thirdly, he argued that the Queen was the head of society.

Bagehot readily admitted that the Prime Minister could quite easily be the head of society and in any case intellectuals (Bagehot calls them 'philosophers') would not be easily impressed by the claims to sanctity around the monarch. However, the English are 'perhaps the least a nation of pure philosophers' (Bagehot 2009:40). For Bagehot the authority of a Prime Minister is limited by elections and hence they retire on a regular basis, and therefore it is the monarchy that expresses the continuity of a nation. Fourthly, we have to regard monarchy as the vehicle of public morality. The virtues of Queen Victoria and George111, he suggested, had had a large impact on public onion and behaviour. Finally, Bagehot argued that monarchy functioned to disguise the underlying changes taking place in society and government. To use the language of Pierre Bourdieu, the Crown is the illusio of permanence, celebrated in the proclamation at the death of a monarch 'The King is dead; long live the King!' Hence the real value of constitutional monarchy is that in times of great crisis it can provide the illusion of stability. This argument may account for the emotional support that surrounded the royal family during the blitz of London.

Having described the symbolic role of monarchy Bagehot concluded by arguing that the efficient powers of the Queen in a constitutional monarchy were rightly limited to three activities-she had a right to be consulted; the right to encourage; and the right to warn ministers. While there is no 'blue-book' to say what she should do, the customary role of the monarch were severely limited. The mystery surrounding the symbolic power of the Queen would be rapidly corrupted by any contact with day-to-day politics. Of course, he recognised that these arrangements and the three types of rights often failed to separate the monarch from cabinet government. George111 interfered with government too frequently according to Bagehot, who called him a 'meddling maniac' (Bagehot 2009: 55). Nevertheless the advantage of 'a constitutional king is the permanence of his place' (Bagehot 2009:54). Political affairs are 'vast, disagreeable, complicated and miscellaneous' (Bagehot 2009: 54). A king, who stays on the throne for a life time, can learn political virtues of prudence which are invaluable and, if he works tirelessly in support of his ministers the government, can benefit. Bagehot recognised all too well that this happy combination of circumstances is rare-'Such kings are among God's greatest gifts, but they are also among His rarest' (Bagehot 2009: 54).

\section{The Coronation and the Intellectuals}

The rituals that surround the British monarchy have become important topics of sociological research, most notably by Edward Shils and Michael Young who published 'The Meaning of the Coronation' in 1953. Their essay was based in part on observations they made of street parties in the East End of London. The Coronation was a ceremonial and celebration of the moral values of the society. The Coronation re-affirmed the bonds of family, community and nation within a religious ritual. It was in fact an act of, 'national communion' (Shils and Young 1953: 80). The celebrations at the time have to be understood in the context of economic scarcity after the War that continued into the 1950s and the decline of British imperial power.

Shils (1975) thought of cultures in terms of centre and periphery, arguing that, while some people were oriented towards the core components and manifestations of a 
tradition, other individuals and groups stood on the periphery. These different aspects of a culture command different levels of loyalty and manifest different degrees of bonding to society. According to Shils and Young the Coronation of Elizabeth11 evoked emotional responses from the people, because the coronation rituals were symbolic of the centre of national tradition. Shils recognised that many intellectuals were either critical of or sceptical towards such national rituals. Intellectuals are trained in terms of these core values, but because they are paradoxically its guardians, they become intensely critical of its actual manifestations, where these are felt to be inadequate or contrived (Shils 1972) It is interesting that Shils and Young were often criticised for naively assuming that the coronation demonstrated unquestioning popular support for monarchy (Abercrombie et al. 1980). The Shils and Young article was taken to be representative of the tradition of American sociology in which sociologists such as Talcott Parsons exaggerated the presence of a central value system in modern societies. Intellectuals are therefore inclined to argue that, while the media often create the impression of unified and coherent attitudes, media studies tend to show that audiences are diverse and fragmented. Consequently events such as the coronation have many meanings, some of which will be discordant. Similarly responses to Princess Diana's death have to be read carefully, because the public outburst represented a range of meanings and attitudes (Thomas 2002). In short, traditions are invented (Cannadine 1983). In Britain, the Left naturally regards the survival of the monarchy as either typical of political gradualism in English history or has assumed that monarchy will not survive indefinitely in a democracy (Nairn 1994).

The response to the royal wedding of Prince William and Kate Middleton received a similar reaction from intellectuals. There was obviously mass enthusiasm for the wedding with over three million people on the streets of central London and with a world-wide audience of some three billion. Nevertheless the response of intellectuals and serious journalists was cautious or dismissive. In the Financial Times, Philip Stephens (2011:9) referred in passing to the 'fuss and flummery surrounding the royal couple' and predicted that 'the institution's long-term survival will depend on whether it manages to adapt to straightened circumstances'. The headline of the FT Weekend (Sunday April 24 2011, p 1) warned that the royal family is 'a changed, chastened institution, and no one is banking on its future'(Engel 2011:1).In its 'Week in Review' The New York Times (April 24, 2011, p. 7) under the banner 'This Tarnished Crown' asserted that 'For many in Britain, the royal marriage on Friday is seen less as a step toward saving a sullied monarchy - as an uncertain step, at that'(Burns 2011:1).
Simon Schama the distinguished historian, writing about the wedding and royalty in The Financial Times (April 30, 2011: 7) against the background of authoritarian dynasties in North Africa and Middle East, concluded the royal couple were a 'much less harrowing spectacle of two-good looking kids at the altar, doing their I-dos for the nation and for each other, at worst a harmless distraction; even perhaps worth a bit of a national knees-up'. How then to explain the spectacle of three million people on the London streets and the billions around the globe watching this 'harmless distraction'? In addition, how to explain the huge popularity of a series of recent films such as Elizabeth, The Queen and The King's Speech ?Perhaps we need to return to reread Bagehot as the only reliable guide to the social and constitutional framework of monarchy

\section{Why the English Need a Monarch}

Perhaps the obvious place to start is that Great Britain is in a deep crisis. It faces the worst economic depression since the 1930s, the economy is stalled and the pound has been in steep decline. Britain was in need of some good news in order, as Schama puts it, to have a good 'knees-up'. Unemployment and social unrest in the face of economic austerity have been only too evident in the capital. Local elections and the debate about the voting system have served to highlight the fragility of the Coalition Government and the precarious status of the constitution of the United Kingdom. There is some degree of agreement among political commentators that Scotland will achieve independence by 2020 if not earlier. In this instance, independence may not extend to secession, but it will signal the break-up of an historic union. This development pinpoints the fact that the Crown is one of the few remaining institutions that binds the United Kingdom of Great Britain and Northern Ireland into a single political system.

The role of the Queen, which appeals as much to Scottish symbolism as it does to English rituals, is crucial in this constitutional evolution. It should also remind us that Queens rather than Kings have been the cultural as well as the social glue of Great Britain (Waller 2006). TheyElizabeth 1 and Victoria-have certainly been more popular and long-lasting than most English kings. Following Bagehot's argument about national coherence, Queen Elizabeth11 in the twentieth century (and Victoria in the nineteenth century) become a symbol of national continuity, given the length of her reign and her capacity to survive domestic and national crises as she did in what she called the annus horribilus in 1992, making an ironic twist to the phrase annus mirablis that the poet John Dryden had used to describe the Fire of London in 1666. British Prime 
Ministers come and go, but the Queen, who will celebrate her Diamond Jubilee in 2012, appears to have the stamina to outlast them all. This interpretation of monarchy was the principal conclusion of Ben Pimlott's authoritative political biography of Elizabeth 11 in which he sympathetically argued that monarchy was a benign force in providing some stability to British public life. The book is remarkable in that Pimplott, who was the Warden of Goldsmiths, had been a staunch supporter of the British Labour Party and a major Fabian political philosopher (Pimlott 2001). He recognised the religious significance of monarchy in British life.

In one respect of course, the connection between the Crown and the Church of England has become a problem with the steep decline of Anglicanism not only in Great Britain but also in the Commonwealth. In this regard, the Coronation Oath which William will take eventually will commit him to the defence of Protestantism and the supremacy of the Church of England. This is a difficult role to sustain in a society as deeply secular as Britain. While these weddings and coronations cannot fulfill any ritual re-affirming the dominance of Anglicanism, the Shils-Young argument can be restated to suggest that these public events are secular rituals that reaffirm what Daniele Hervieu-Leger (2000) has called the 'chain of memory'. These rituals revivify our own memory of marriage, of our connection to our parents and grandparents, and our hope of continuity within our own families, and they form a connection, however fragile and unclear, between family and nation.

Secondly, as Bagehot noticed, the idea of a Royal Family was a significant development over and against a solitary monarch. The royal wedding of William and Kate, as so many noticed, was also an attempt to heal the legacy of the divorce between Charles and Diana, and her subsequent tragic and very public death. In a society where the majority of marriages end in divorce within the first 7 years, the 'fairy-tale' royal wedding was a public celebration of the imaginary weddings and happiness we all crave. The marriage promise of loyalty and commitment fulfills this illusio of stability and contentment. A happy Royal Family can be the imaginary family we do not have.

Why are intellectuals in general and sociologists in particular so frequently out of step with the national mood? Why were we taken aback by the outpouring of grief for Diana who was widely regarded as the people's princess? One answer is that intellectuals and the journalists of serious newspapers are an educated and privileged stratum. They have historically been an elite and therefore by definition outside the mainstream, and the gap between the highly educated elite within the university system and the mass of the population may be increasinging in the current economic crisis when university tuition fees are rising. The enthusiasm of the majority for the Royal Wedding was only matched by the disdain of the academic historians who remind us that many 'British monarchs' were in fact not English at all but the offspring of Scottish, Orange or Hanovarian households.

However the real gap between the elite and the mass, at least in the British case, is that intellectuals are secular in three senses of the word. They are very rarely connected in any active way with organised religion and therefore in the Royal Wedding they would have no sympathy with or empathy for Anglican tradition. These ceremonials are 'fuss and flummery'. More importantly, intellectuals are secular in the informal sense of having little or no connection with postinstitutional spirituality or implicit religion (Bailey 1983).It would also appear that British academics, unlike their American peers, have no feeling for patriotic aspects of these public religions and in addition a tradition of civil religion never really developed in Britain. The contrast with America is once again striking, given the attention to the idea of civil religion in American sociology (Bellah 1967). Although British sociology has produced influential sociologists of religion (such as Bryan Wilson and David Martin), the majority of British sociologists in the second half of the twentieth century were simply not interested in religion or religious institutions. While the majority of the population are no longer belonging to any organised religion, there is plenty of evidence in the general public of believing (Davie 1994). Consequently there is therefore no elective affinity between the life-world of academic sociology and the everyday experiences of the people for whom the Royal Wedding was without doubt relief from their current austerity. The Royals now have celebrity status alongside but more enduring than British filmstars and sports people. To call this 'harmless distraction' is however to seriously underestimate the power of these collective rituals for the majority.

There is one final difference between the monarch in mid-century Victorian England and early twenty-first century Britain that did not feature in Bagehot's account of the functions of the Crown. The monarchy is now an important aspect of post-industrial Britain where manufacturing has been replaced by service and leisure industries, and especially by the so-called invisible earnings of the City. One does not have to be excessively pragmatic to realise that the Crown is an economic asset for the tourist industry, for British fashion and in branding the British lifestyle. Kate Middleton's dress will be an important driving force in the resurgence of British fashion and the Royal Wedding should be regarded as an important part of swinging London alongside British football and the Olympic games. In a consumer economy driven by style, the younger members of the Royal Family can play a role as celebrities in reviving the idea that London rather than New York and Paris is the place to be. This is where the 'the flummery' at least comes into its own. In conclusion and in response to John Adams, a constitutional monarch 
need not contradict the very foundations of a functional democracy, providing he or she is kept in check by an elected parliament and an effective cabinet, and in return the monarch can, following Bagehot's recommendations, offer wise counsel on the basis of experience.

Having said that, nobody can guarantee in advance that the hereditary principle will deliver a wise and competent monarch. English monarchs, unlike HenryV111, Elizabeth 1 and James 1, have not always been clever and colorful, but they have not been 'meddling maniacs' either. It would not be prudent to say categorically how a line of American presidents would compare with a line of English monarchs in terms of virtue. Perhaps charitably speaking, there would be nothing to choose.

\section{Further Reading}

Abercrombie, N., Hill, S., \& Turner, B. S. 1980. The dominant ideology thesis. London: Allen and Unwin.

Bagehot, W. 2009. The English constitution. Project Gutenberg Ebook (www.gutenberg.org/files/4351/4351-h/4351-h.htm) Accessed 11 May 2011

Bailey, E. 1983. The implicit religion of contemporary society: An orientation and a plea for its study. Religion Journal of Religion and Religions, 8, 69-83.

Bellah, R. 1967. Civil religion in America. Daedalus, 96(Winter), 1-27.

Black, J. 2006. George 111: America's last king. New Haven: Yale University Press.

Burns, J. F. 2011. "This tarnished crown." The New York Times, April 24 , pp. 1 and 5 .

Butterfield, H. 1957. George 111 and the historians. London: Collins.

Cannadine, D. 1983. The context, performance and meaning of ritual: The British monarchy and the 'invention of tradition' c. 1820-1977. In E. Hobsbawm \& T. Ranger (Eds.), The invention of tradition (pp. 101-164). Cambridge: Cambridge University Press.

Davie, G. 1994. Religion in Britain since 1945, believing without belonging. Oxford: Blackwell.

Ellis, J. J. 1993. Passionate sage. The character and legacy of John Adams. New York: W. W. Norton.
Engel, M. 2011. "Kate expectations." Financial Times, April 22, pp. $1-2$.

Harris, L. 1966. Long to reign over us? the status of the royal family in the sixties. London: Kimber.

Hervieu-Leger, D. 2000. Religion as a chain of memory. Cambridge: Polity.

Judt, T. 2005. Postwar. A history of Europe since 1945. New York: Penguin.

Nairn, T. 1994. The enchanted glass. Britain and its monarchy (2nd ed.). London: Vintage.

Pares, R. 1953. King George 111 and the politicians. Oxford: Oxford University Press.

Parsons, T. 2007. American society. A theory of the societal community. Boulder: Paradigm.

Phillips, K. 2008. Bad money. Reckless finance, failed politics, and the global crisis of American capitalism. Melbourne: Scribe.

Pimlott, B. 2001. The Queen. Elizabeth 11 and the monarchy. London: HarperCollins.

Putnam, R. D., \& Campbell, D. E. 2010. American grace. How religion divides and unites us. New York: Simon \& Schuster.

Schama, S. 2011. "Dynastic lessons from the familiar Windsor flourish." Financial Times, 30 April-1 May, p. 7.

Shils, E. 1972. The intellectuals and the powers and other essays. Chicago: University of Chicago Press.

Shils, E. A., \& Young, M. 1953. "The meaning of the coronation." The sociological review, 3: 63-81 (reprinted in Edward A. Shils (1975) Center and periphery. Chicago: University of Chicago Press.)

Shklar, J. H. 1991. American citizenship. The quest for inclusion. Cambridge: Harvard University Press

Stephens, P. 2011. "Confessions of a lapsed republican." Financial Times, 29 April, p. 9.

Thomas, J. 2002. Diana's mourning. A people's history. Cardiff: University of Wales Press.

Veblen, T. 1899. The theory of the leisure class. Harmondsworth: Penguin.

Waller, M. 2006. Sovereign ladies. The six reigning queens of England. London: John Murray.

Wilentz, S. 2005. The rise of American democracy. Jefferson to Lincoln. New York and London: W.W.Norton.

Bryan S. Turner is Senior Editor of Society and the Presidential Professor of Sociology and Director of the Committee on Religion at CUNY. 